\title{
Factors Used for Effective Awareness of Climate Change among Social Studies Teachers in Delta State.
}

\author{
Dania, P. 0. \\ Department of Social Science Education, \\ Delta State University, Abraka. \\ Obro Sunday \\ Department of Social Science Education, \\ Delta State University, Abraka.
}

\begin{abstract}
This study focuses on factors used for effective awareness of climate change among Social Studies teachers in Delta State. Four research questions and four research hypothesis were used for the study. The research design used is a descriptive survey. The population of the study consists of 556 Social studies teachers in Delta State. The sample used is (120) one hundred and twenty Social studies teachers. The multi-stage random sampling technique was adopted for the study. The instrument for the study was the questionnaire tagged "FUEACCQ". Test re-test method of determining the reliability was used to establish the reliability of the instrument. The Pearson Moment Correlation used to analyse the instrument; it gave a value of 0.78 . The z-test statistical tool was used for the analysis of the data collected at 0.05 probability level. The findings revealed that internet facilities enhances climate changes awareness among Social Studies teachers in Delta State; community campaign help in climate change awareness among Social Studies teachers in Delta State; media enhances climate changes awareness among Social Studies teachers in Delta State; seminar/workshop enhances climate changes awareness among Social Studies teachers in Delta State. Based on findings, it is recommended that government should make provisions of internet facilities to enhance climate change awareness among Social Studies teachers in Delta State should be taken seriously to inform the public on the effectiveness of climate change awareness.
\end{abstract}

Key Words: Effective Awareness; Climate Change; Social Studies Teachers.

\section{INTRODUCTION}

Climate change implies a rise in average global temperature ranges or conditions. Some of the factors thought to be contributing to climate change are human activities and natural happenings. This is brought on mainly by upsurge in greenhouse gases such as carbon dioxide (Co2). Nigeria is experiencing undesirable effects of climate condition with negative effects on the welfare of the people. Persistent drought and flooding, off seasons rains and dry spells have sent growing seasons out of orbit, on a country dependent on a raid fed agriculture. Distress calls are being made with water bodies drying up and a decrease in river flow in the arid and semi-arid region. This has led to shortage of water supplies for use in agriculture, human consumption, and hydroelectric power as well as others. The primary suspect for all of this havoc is climate change (Arunkumar, 2012).

Climate change has been defined as a phenomenon created by human beings and nature. Which devastates the earth and causes hardship of unpredicted magnitude to the living. Inter govern mental panel can climate change. Additionally, it is known as global warming or global 
weather patterns. Udenji (2010) opined that climate change is simply a change in the climate condition of the world and that the change is found by the scientists and others to be on the negative. Udenji (2010) defines climate change as extreme reactions of the weather phenomenon which is negative impact of agricultural water resources, human health, and depletions of the soil, ozone layers, vegetation, and expanding of $\mathrm{CO} 2$ in the ecosystem.

Omotosho (2009) explain climate change as an alteration of environment or climate that is attributed to the direct or indirect human activities and the atmosphere. Scientist have intensified the greenhouse impact by increasing the focus of greenhouse gasses in the atmosphere. He posted that climate change means average global temperature triggered by the natural occurrences or happenings and human activities that are thought to be contributing to a rise in average global temperatures.

Change is an environmental, social and economic challenge on a global scale. It could be aggravated by man-made actions including the extensive utilization of land, the broad scale deforestation, the major technological and socio-economic shift with minimal reliance on organic and natural fuel and the accelerated up take of fossils fuel (Fabiyi, 2007) It can be exacerbated by human induced actions such as the widespread use of land, the broad scale deforestation, the major technological and socio-economic shift with reduced reliance on organic fuel and the accelerated up take of fossils fuel (Summers, Kruger \& Childs, 2000).

According to Ozor (2009), climate change is severely affecting livelihood in Nigeria by altering seasonal, rainfall patterns, streams are spring are drying up causing major crop yield and food shortage. However the level of awareness of climate change impacts is very low. Corporations and the transport sector. The major perpetration of this damage, have even begun to take the necessary actions to address these problems no abatement measures are been implemented to stop gas flaring. Nigerian main source of greenhouse gas emission. In the study of indigenous people perception on climate change and adaptation strategies in Jemas Local Government Area of Kaduna State. Nigeria by Ishaya \& Abaye (2008) it was reported that in terms of awareness $13 \%$ of the respondents agreed that there is high level of awareness on climate change in the study area, 33\% of the respondents said they don't know and finally majority $54 \%$ of the respondents declined that the awareness on climate change is very weak in the study area and Nigeria as a whole.

In a research carried out by Odey (2009) noted that possibly the major hindrance to reducing the impact of climate change in Nigeria is the lack or dearth of awareness and knowledge of the effect of climate change. Lack of awareness and understanding of climate change does mean that lots of Nigerians, Social Studies teachers inclusive, are unwilling to simply accept the reality of climate change. More so, there's lack or insufficient public policy, commitment and readiness of government in stimulating climate change adaptation approaches in the country. Given the prevailing low level of understanding and awareness of climate change in Nigeria, there is the need to investigate factors used for effective awareness of climate change among Social Studies teachers in Delta State.

\section{STATEMENT OF THE PROBLEM}

Climate change is a tropical issue worldwide because of its attendant problems that are threatening. The sustenance of man and his environment. These are particularly becoming more severe in the wider developed and developing environment. These are particularly becoming more severe in the under developed and developing countries of which Nigeria is 
one. It has become a reality with grievous consequences. The impact of the climate change include floods, landslides, drought and famine. As weather becomes fierce and storm increase in frequency and intensity, series of socio-economic consequences results. Malnutrition and diseases becomes the other of the day.

The effects of climate change range from drought event to flooding events, sea level rise, drying of rivers, streams, decrease in water quality, melting of glaciers, loss of biodiversity, change in rainfall pattern and amounts, increase in temperature among others. These effects have negative impact on the economy, food security, agricultural production, health and social statuses (conflicts and migration) of many nations, especially the developing countries (Nigeria in particular).

There are noticeable consequences of climate change in Nigeria such as intense thunderstorms, widespread flood and incessant drought. Odey (2009) has pointed out that climate change impact pose great dangers with consequences such as dissertation, sea level rise, flooding water, salination among others. These impact could manifest in food security challenges, damage to infrastructural and social dislocations. Additional impacts includes threats to health as rising temperature could bring about disease such as chronic heat, ashes, cerebral spinal meningitis, stroke, malaria and other related diseases. Climate change will affect every citizen. Parts of our environment, natural resources, our urban and suburban development patterns and thus every aspect of our life, (Enoh, 2009).

\section{RESEARCH QUESTIONS}

i. Does internet facility enhance climate change awareness among Social Studies Teachers in Delta State?

ii. Is there any significant relationship between media and awareness on climate change among Social Studies Teachers in Delta State?

iii. Does community campaign affect the awareness of climate change among Social Studies Teachers in Delta State?

iv. Is there any significant relationship between seminar/workshop and climate change awareness among Social Studies Teachers in Delta State?

\section{Hypotheses}

i. There is no significant relationship between internet facilities and climate change awareness among Social Studies teachers in Delta State.

ii. There is no significant relationship between media and awareness on climate change among Social Studies teachers in Delta State.

iii. There is no significant relationship between community campaign and climate change awareness among Social Studies teachers in Delta State.

iv. There is no significant relationship between seminar/workshop and climate change awareness among Social Studies teachers in Delta State.

\section{Research Design}

\section{METHODOLOGY}

The study adopted descriptive survey research design. This design was used because the study aimed at collecting data on, and describing in a systematic manner, the characteristics, features or facts about the population under study. 


\section{Population of the Study}

The population of the study comprised of five hundred and fifty-six Social Studies teachers' in Delta State.

\section{Sample and Sampling Techniques}

From the target population, a sample size of one hundred and twenty Social Studies teachers from the three senatorial districts in Delta State. The sample for the study was drawn using the multi-stage random sampling technique.

\section{Instruments of the Study}

The instrument for the study was the questionnaire tagged "FUEACCQ". It consisted of two parts, part " $A$ " and " $B$ ". Part " $A$ " contained personal data of the respondent, while part " $B$ " comprised of twenty (20) items. The items in this section were rated on 4 points scale as follows: SA (Strongly Agree), A (Agree), D (Disagree), and S.D (Strongly Disagree).

\section{Reliability of the Instrument}

Test re-test method of determining the reliability was used to establish the reliability of the instrument. The Pearson Moment Correlation used to analyse the instrument; it gave a value of 0.78 .

\section{Data Analysis}

The z-test statistical tool was used for the analysis at 0.05 probability level.

\section{Research question 1}

\section{RESULTS}

Does internet facility enhance climate change awareness among Social Studies Teachers in Delta State?

Table 4.1: Summary of Research Question 1

\begin{tabular}{|l|l|l|}
\hline Options & Frequency & Percentage (\%) \\
\hline Strongly agreed & 80 & 66.6 \\
\hline Agreed & - & - \\
\hline Strongly disagreed & - & - \\
\hline Disagree & 40 & 33.3 \\
\hline Total & 120 & 100 \\
\hline
\end{tabular}

From the table above, it and be shown that $66.6 \%$ of the percentage of respondents strongly agreed that internet facilities enhances climate change awareness among Social Studies teachers in Delta State, while 33.3\% of the total population disagreed to the view that internet facility enhances climate change awareness among Social Studies teachers in Delta State.

\section{Research Question 2}

Is there any significant relationship between media and awareness on climate change among Social Studies teachers in Delta State? 
Table 4.2: Summary Research Question 2

\begin{tabular}{|l|l|l|}
\hline Options & Frequency & Percentage (\%) \\
\hline Strongly agreed & 60 & 50 \\
\hline Agreed & 10 & 8.3 \\
\hline Strongly disagreed & - & - \\
\hline Disagree & 50 & 41.6 \\
\hline Total & 120 & 100 \\
\hline
\end{tabular}

From the table above, it is gathered that $50 \%$ of the responses strongly agreed that there is a significant relationship between media and awareness on climate change among Social Studies teachers in Delta State, while $41.6 \%$ of the total responses disagreed to the statement.

\section{Research Question 3}

Does community campaign affect the awareness of climate change among Social Studies teachers in Delta State?

Table 4.3: Summary of Research Question 3

\begin{tabular}{|l|l|l|}
\hline Options & Frequency & Percentage (\%) \\
\hline Strongly agreed & 40 & 33.3 \\
\hline Agreed & - & - \\
\hline Strongly disagreed & 80 & 66.6 \\
\hline Disagree & - & - \\
\hline Total & 120 & 100 \\
\hline
\end{tabular}

From the summary research questions 3 above, it can be deduced that $33.3 \%$ of the respondents strongly agreed to the view that community campaign affect the awareness of climate change among Social Studies teachers in Delta State, while $66.6 \%$ did not agree to the statement.

\section{Research Question 4}

Is there any significant relationship between seminars, workshops and climate change among Social Studies teachers in Delta State?

Table 4.4: Summary of Research Question 4

\begin{tabular}{|l|l|l|}
\hline Options & Frequency & Percentage (\%) \\
\hline Strongly agreed & 120 & 100 \\
\hline Agreed & - & - \\
\hline Strongly disagreed & - & - \\
\hline Disagree & - & - \\
\hline Total & 120 & 100 \\
\hline
\end{tabular}

From the summary research questions 4 above, it is observed that $100 \%$ of the respondents strongly agreed to the fact that seminar and workshops enhances climate change, awareness among Social Studies teachers in Delta State.

\section{Testing the hypothesis 1}

Ho1: There is no significant relationship between internet facilities and climate change awareness among Social Studies teachers in Delta State. 
Table 4.5: z-Test Analysis of internet facilities and climate change awareness among Social Studies teachers in Delta State.

\begin{tabular}{|l|c|c|c|c|c|c|}
\hline \multicolumn{1}{|c|}{ Variable } & N & X & SD & df & t-Cal & t-Crit. \\
\hline $\begin{array}{l}\text { internet and climate change } \\
\text { awareness among Social Studies } \\
\text { teachers }\end{array}$ & 120 & 38.24 & 4.33 & 118 & 2.19 & 1.96 \\
\hline
\end{tabular}

From the table 4.5 it showed that the calculated table value of 1.96 is greater than the critical table value of 2.19 at 0.05 level of significance. Therefore the null hypothesis 1 is rejected. The results then shows that there is a significant relationship between internet facilities and climate change awareness among Social Studies teachers in Delta State.

\section{Hypothesis 2:}

There is no significant relationship between media and awareness on climate change among Social Studies teachers in Delta State.

Table 4.6: z-Test Analysis of relationship between media and awareness on climate change among Social Studies teachers in Delta State.

\begin{tabular}{|l|l|l|l|l|l|l|l|}
\hline Variable & N & X & SD & df & t-Cal. & t-Crit. \\
\hline $\begin{array}{l}\text { Media and awareness on climate } \\
\text { change }\end{array}$ & 120 & 58.04 & 6.72 & 118 & 2.96 & 1.96 \\
\hline
\end{tabular}

From the result in table 4.6, it revealed that the calculated table value 2.96 is greater than the critical table 1.96 at 0.05 level of significance, therefore the null hypothesis 2 is rejected. The results therefore shows that there is a significant relationship between media and awareness on climate change among Social Studies teachers in Delta State.

\section{Hypothesis 3:}

There is no significant relationship between community campaign and climate change awareness among Social Studies teachers in Delta State.

Table 4.7: z-Test Analysis of relationship between community campaign and climate change awareness among Social Studies teachers in Delta State.

\begin{tabular}{|l|l|l|l|l|l|l|}
\hline Variable & $\mathbf{N}$ & $\mathbf{X}$ & SD & df & t-Cal. & t-Crit. \\
\hline $\begin{array}{l}\text { Community campaign and climate } \\
\text { change awareness }\end{array}$ & 120 & 60.12 & 18.21 & 118 & 3.16 & 1.96 \\
\hline
\end{tabular}

From table 4.7, the result indicated that there is a significant relationship between community campaign and awareness of climate change among Social Studies teachers in Delta State. This is because calculated value of 3.16 is greater than the critical table value of 1.96 at 0.05 level of significance. Therefore the null hypothesis is rejected. The results then shows that there is a significant relationship between community campaign and awareness of climate change among Social Studies teachers in Delta State.

\section{Hypothesis 4:}

There is no significant relationship between seminar/workshop and climate change awareness among Social Studies teachers in Delta State. 
Table 4.8: z-Test Analysis of relationship between seminar/workshop and climate change awareness among Social Studies teachers in Delta State.

\begin{tabular}{|ll|l|l|l|l|l|l|}
\hline Variable & & $\mathbf{N}$ & $\mathbf{X}$ & SD & df & t-Cal. & t-Crit. \\
\hline $\begin{array}{l}\text { Seminar/workshop } \\
\text { change awareness }\end{array}$ & and climate & 120 & 60.44 & 17.43 & 118 & 2.92 & 1.96 \\
\hline
\end{tabular}

Analysis of the hypothesis 4 in table 4.8 shows that there is significant relationship between seminar/workshop and climate change awareness among Social Studies teachers in Delta State. This because the calculated table value of 1.96 is greater than the critical value at 0.05 level of significance. Therefore the null hypothesis 5 is rejected. The results then shows that there is a significant relationship between seminar/workshop and climate change awareness.

\section{Discussion of the Results of Hypothesis 1}

\section{DISCUSSION}

The results of hypothesis 1 shows that there is a significant relationship between internet facilities and climate change awareness among Social Studies teachers in Delta State. Form the analysis above, it can be seen that internet facilities enhances climate change among Social Studies teachers. This finding is in line with the work of Akintola (2010) who observed that the internet have a duty as a spring board of information and perception climate change are critical affected by the internet. Thus, the finding was not out of place.

\section{Discussion of the Results of Hypothesis 2}

The result of hypothesis two affirmed that therefore shows that there is a significant relationship between media and awareness on climate change among Social Studies teachers in Delta State. This finding is in agreement with Nimishkapoor (2011), Apolinary (2011) who reported that the media have so far played a leading role in educating and informing the public on effects of environmental deterioration and related human impacts but little has been done on climate change. It have the responsibility as a source of information and opinions about ethical consumption, public perception and attitude with regards to these domain are significantly influenced by representation of knowledge (scientifically) conveyed by the press and by other mass means of communication. Actually following the recent development of cultural and uses and gratification paradigms, empirical evidence shows the relationship between environmental concern. Television viewing and pro-environmental behaviours. Thus, highlighting the effect of various forms of televise viewing and potential mediating roles in the relationship between environmental attitudes and behaviour operations of codification of the issue into the media discuss are directed and controlled by the perceived interest and social impact of a topic as well as other new values. Indeed mass media not only conveys knowledge and attitudes but actually by focusing on specific social meanings.

\section{Discussion of the Results of Hypothesis 3}

The result of hypothesis 3 showed that there is a significant relationship between the community campaign and climate change awareness among Social Studies teachers in Delta State. This is observed that the community campaign can create the awareness among the people based on the issue of climate change. This observed information is in line with the work of Omotosho (2007) who stressed that indeed community campaign are among policy tools mostly commonly used to attempt to influence public opinion in particular issues. The influence of the mass media on public option has been shown to be quite short lived to issues often from day to day. Many campaign programme in various environment fields including energy conservations campaign have used the mass media. 


\section{Discussion of the Results of Hypothesis 4}

The result of hypothesis 4 indicated that there is a significant relationship between seminar/workshop and climate change awareness among Social Studies teachers in Delta State. It was gathered that seminar and workshops enhance climate change awareness. This finding is in conformity Ishaya \& Abaye (2008) and Spore (2008), who reported that seminars and workshops help to increase information and knowledge about climate change thereby making many Nigerians to accept the reality. Also, seminars and workshop help to bring to fore public policy, government preparedness and commitment as well as promotion of climate change adaptation strategies in the country.

This finding of this study is also in line with the work of Omostosho (2007) who stressed that seminar workshop can address groups of people in a region affected by a particular climate threat group of stakeholders, the general public. It also addresses the knowledge of individuals and organization. It aim at ensuring all relevant regional and sub-regional bodies understand the impact of an action to respond to certain climate impact such seminar or workshops are considered effective. If several ways of communications are served, dissemination of printed materials organizations public meeting and training professional consultants and information through social and mass media using informal network for information dissemination.

\section{Conclusion of the Study}

\section{CONCLUSION AND RECOMMENDATIONS}

The study has reviewed the factors used for effective awareness of climate change among Social Studies teachers in Delta State. These factors are the internet, mass media, community campaign, seminars and workshops. The study revealed that there exist a positive relationship between the internet, mass media, community campaign, seminars and workshops and climate change awareness among Social Studies teachers in Delta State. That is these are the factors that bring about effective awareness of climate change among Social Studies teachers in Delta State.

\section{Recommendations}

1. Policy makers should tap into the vast practical of the media to disseminate climate change information and create more awareness about causes and consequences of climate change adaptation.

2. Indigenous adaptive strategies in science, technology and innovation (STI) policy relevance should inform the design and implementation of climate change policy in Nigerian.

3. There is should be more robust collaboration among stakeholders in the evolving innovative approaches and adaptive measures for the climate change phenomenon in Nigeria.

4. In addition, adequate investment in research and capacity building should be undertaken so as to build resilient adaptation to climate change impact in Nigeria.

5. More seminars and workshop should be organise for teachers so as to keep them abreast with more and latest information on climate change.

\section{References}

Abaye, B. (2008). Socio-economic Climate Change Impacts on Agriculture: An Integrated Assessment, 1990-2080. GeoJournal, 72, 94-139

Akintola, A. (2010). Democracy Oil and Politics in the Niger Delta. Linking Citizens Perception and Reforms. Port Harcourt: Center of Advance Social Science. 
Dania, P.O. \& Sunday, O. (2017). Factors Used for Effective Awareness of Climate Change among Social Studies Teachers in Delta State. Advances in Social Sciences Research Journal, 4(2) 50-58.

Apolinary, T. (2011). Economics and Policy Issues in Climate Change. Washington D. C.: Resources for the future. Arunkumar, J. (2012). A Study on Assessment of Environmental Awareness among Teacher Trainees in Teacher Training Institutes. International Journal of Research in Social Sciences, 2(3), 312-336

Enoh, D. E. (2009). Agricultural Impact of and Response to Climate Change in the Missouri Iowa Nebraska. Reign Climate change, 24(1), 23-62.

Fabiyi, O. O. (2007). Analysis of Change- Agents in Urban Land Use Transition; Example from Ibadan City, Nigeria. J. Environ. Cult, 4(2): 23-43.

Ishaya, S.1 \& Abaje, I. B (2008). Indigenous people's perception on climate change and adaptation strategies in Jema"a local government area of Kaduna State, Nigeria. Journal of Geography and Regional Planning, 1(8), 138143 ,

Nimishkapoor, E. (2011). The Perception of an Adaptation to Climate Change in Africa. (EGPA Discussion Paper, No, 10).

Odey, C. K. (2009). The Effects of Gas Flaring on Crops in Nigeria. GeoJournal, 73, 297-305.

Omotosho, S. P. (2009). Climate change and the Nigerian environment. Conference proceedings. Noukka Department of Geography, University of Nigeria.

Ozor, N. (2009) Implications of Climate Change for National Development: The Way Forward. Debating Policy Options for National Development; Enugu Forum Policy Paper 10; African Institute for Applied Economics (AIAE); Enugu, Nigeria: 19-32.

Spore, L. K. (2008). Agricultural Impacts of Climate: If Adaptation the Answer, What is the Question? Climate change, 45, 529-539.

Udenji, S. (2010). Climate Change and Environmental Degradation in Nigeria. Research Journal of Applied Sciences, 3(3), 167-173. 